\title{
SYNTHESIS AND ANALYSIS OF COPPER PROTEINATE AND MANGANESE PROTEINATE FROM REACTION OF COPPER SULFATE AND MANGANESE SULFATE WITH PROTEIN EXTRACTED FROM FISH WASTE
}

\author{
HARMITA HARMITA*, DANNIS SAMUEL SIMBOLON
}

Department of Pharmacy, Faculty of Pharmacy, Universitas Indonesia, Depok, Indonesia. Email: igakadeharmita@gmail.com Received: 26 September 2019, Revised and Accepted: 17 December 2019

ABSTRACT

Objective: Copper and manganese are essential minerals needed for various biological processes in small amounts. However, essential minerals are poorly absorbed in the form of salts or free form, leading to their low bioavailability. Forming complexes of essential minerals with protein can increase their bioavailability. Metal proteinate complexes are non-polar, thereby reducing their excretion from the body. Fish waste is quite abundant in Indonesia, and therefore, we used fish waste to synthesize metal-proteinate complexes.

Methods: Protein was extracted from fish waste using pancreatin. The extracted protein was mixed with copper or manganese in various ratios. The metal content in the complexes was analyzed using atomic absorption spectrophotometry; ion exchange chromatography was used for separating the complexes from free unbound metals.

Results: The optimum condition which yielded the highest protein content was the ratio of pancreatin enzyme to fish waste powder of $2: 100$. The optimum concentration of pancreatin was found to be $2 \%$ of the substrate. The yield of copper-proteinate complexes ranged from $97.87 \%$ to $98.55 \%$, whereas the yield of manganese proteinate ranged from $97.05 \%$ to $98.36 \%$. The free metal content was only found in the manganese proteinate complex in the $1.2: 1$ ratio, which was determined to be $0.0198 \mathrm{mg} / \mathrm{g}$.

Conclusion: We demonstrated that copper and manganese can react with proteins extracted by enzymatic hydrolysis of fish waste.

Keywords: Copper, Manganese, Protein, Complexes, Metal, Proteinate, Atomic absorption spectrophotometry, Ion exchange chromatography.

(c) 2020 The Authors. Published by Innovare Academic Sciences Pvt Ltd. This is an open access article under the CC BY license (http://creativecommons. org/licenses/by/4. 0/) D0I: http://dx.doi.org/10.22159/ijap.2020.v12s1.FF031

\section{INTRODUCTION}

Fish waste comprises various body parts from fish, such as the head, skin, stomach contents, fins, bones, and eggs [1,2]. Fish waste is generally discarded rather than being used for other applications $[3,4]$.

Converting fish waste into useful compounds such as drugs or functional foods that use protein ingredients is a solution to this problem [5]. Fish waste contains protein, fat, amino acids, minerals, enzymes, peptides, collagen, and gelatin [6,7]. Chemical hydrolysis produces heterogeneous and non-specific peptides which reduce protein quality, whereas enzymatic reaction produces a more precise and better quality hydrolyzed protein. Thus, enzymatic reactions using protease enzymes are better than chemical hydrolysis reactions $[7,8]$.

The protein extracted from fish waste can be used as a ligand to form metal proteinate complexes using essential metals, such as $\mathrm{Fe}, \mathrm{Zn}, \mathrm{Cu}$, $\mathrm{Mn}, \mathrm{Mg}$, Ca, Co, Mo, and Cr. All of that is generally easy to be excreted because of their polar nature. However, forming a metal proteinate complex reduces their polar properties, preventing their rapid excretion and is, therefore, better absorbed into tissues [9-16].

The reaction of metals with proteins results in the formation of ions, which can be separated or purified using a cation exchange column. The metal proteinate is retained in the stationary phase of the Amberlite XAD-16 adsorption column, whereas the free metal is easily carried away by the mobile phase flowing out of the column [17].

To date, no metal proteinate has been synthesized using protein extracted from fish waste. In the present study, a proprietary fish waste protein extract was used to synthesize the metal proteinate and demonstrated an increase in the absorption of essential minerals chelated by the protein. This study shows the potential economic benefits derived from fish waste, particularly in the health and wellness industry, where metal proteinate supplements have found a niche market and thereby reduced the problems associated with processing fish waste.

\section{MATERIALS AND METHODS}

\section{Materials}

Fish waste (Local fish market), copper sulfate (Merck-Germany), manganese sulfate (Merck-Germany), pancreatin protease enzyme 4NF (Excellent Biotechnologies), potassium sulfate, copper (II) sulfate pentahydrate or copper (II) oxide, granulated zinc, sulfuric acid $(\mathrm{p} 20=1.84 \mathrm{~g} / \mathrm{ml}), 0.1 \mathrm{M}$ sulfuric acid, methyl red solution $(300 \mathrm{mg}$ in $100 \mathrm{ml}$ ethanol or methanol), $40 \%(\mathrm{~m} / \mathrm{v}$ ) $\mathrm{NaOH}$ solution, $0.25 \mathrm{M}$ and $0.1 \mathrm{M}$ standard $\mathrm{NaOH}$ solution, acetylene, acetanilide $\left(\mathrm{mp}=114^{\circ} \mathrm{C}\right.$, content $\mathrm{N}=10.36 \%$ ), nitrogen-free sucrose, boric acid, solution of methyl red 2 (100 $\mathrm{mg}$ in $100 \mathrm{ml}$ ethanol or methanol), solution of green bromocresol (100 mg in $100 \mathrm{ml}$ ethanol or methanol), boric acid solution (10-40 g/L, according to the apparatus used), standard solution of $0.1 \mathrm{M}$ hydrochloric acid, $65 \%$ nitric acid, methanol, distilled water, acetone, $1.0 \mathrm{M}$ nitric acid in acetone, aquadest, and a solution of 1.0 $\mathrm{M}$ of $\mathrm{NaOH}$ and distilled water were used.

\section{Equipment}

Atomic absorption spectrophotometer (Shimadzu AA-6300) equipped with a hollow-cathode lamp, column chromatograph, silent phase ion exchange chromatograph, and adsorption resin Amberlite XAD-16.

\section{Preparation of fish waste powder}

Approximately $500 \mathrm{~g}$ of fish waste was sun-dried for $8 \mathrm{~h}$, after which the dried fish waste was mashed with a blender to yield a fine powder that was weighed. 
Protein extraction from the enzymatic reaction of fish waste with protease

Protein was extracted from the fish waste by pancreatin $4 \mathrm{NF}$ enzyme - hydrolysis. Dried fish waste powder $(5.0 \mathrm{~g})$ was dissolved in $25 \mathrm{ml}$ distilled water ( $\mathrm{pH}$ 8.0). Pancreatin 4NF (100 mg) was added to the mixture and incubated for $1 \mathrm{~h}$ to allow enzymatic hydrolysis. The mixture was then heated on a water bath for $5 \mathrm{~min}$ to inactivate the enzyme. The protein suspension in water was decanted, and the volume was measured. Of this suspension, $50 \%$ was used to determine protein content by the Kjeldahl method, and the remaining was reacted with metal to synthesize the metal proteinate.

The hydrolysate was washed with $30 \mathrm{ml}$ acetone and incubated for $8 \mathrm{~h}$ at $4^{\circ} \mathrm{C}$. This process separated protein from residual fat; subsequently, protein deposit and acetone were separated by decantation. The protein deposit obtained was then dissolved in $30 \mathrm{ml}$ of $0.6 \%$ sodium chloride solution ( $\mathrm{pH} \mathrm{5.5)}$ and heated on a water bath at $70^{\circ} \mathrm{C}$ for $1 \mathrm{~h}$ to allow the protein to precipitate. The solution was then filtered with a Buchner funnel using a Whatman ${ }^{\circledR}$ filter paper No. 42 equipped with Erlenmeyer reservoirs and vacuum pumps. The protein deposits were trapped on filter paper in the Buchner funnel and sequentially washed with aquadest, ethanol, and ether, as previously described [18].

\section{Synthesis of metal proteinate complexes}

Metal proteinate was synthesized by reacting copper sulfate and manganese sulfate with protein obtained from fish waste. Metal proteinate complexes of three ratios, $0.8: 1,1: 1$, and 1.2:1, were synthesized in this study. Protein concentration, determined by the Kjeldahl method, was used to prepare the metal proteinate complex. Extracted protein was resuspended in $15 \mathrm{ml}$ aquadest and heated on a hotplate until it reached $40^{\circ} \mathrm{C}$. Metal compounds in the proportion described above were added into the suspension to allow metal proteinate complex formation.
Deposits at the bottom of the container were filtered using Millipore $0.22 \mu \mathrm{m}$ filter paper. The yield of the precipitate obtained and the water content was determined. The steps were repeated for other complex formation for comparison purposes [19].

\section{Sample preparation for atomic absorption spectrophotometry (AAS)}

For spectrophotometry, $60 \mathrm{mg}$ of the metal proteinate complex was dissolved in $10 \mathrm{ml} 65 \% \mathrm{HNO}_{3}$ and heated on a hotplate at a temperature of $100^{\circ} \mathrm{C}$ to accelerate the destruction of the complex. Destruction was considered complete if the sample dissolved or no white vapor was released. This resulted in a clear yellow solution with a little residual sediment. The solution was filtered using a 50-ml volumetric flask equipped with a funnel and filter paper at the top to sieve the remaining deposits. The sample was diluted with an appropriate volume of distilled water before AAS.

\section{Separation of free metals from metal proteinate complexes}

Sixty milligrams of the metal-proteinate complex were suspended in distilled water, filtered, and separated by column chromatography with the stationary phase Amberlite XAD-16 resin. The mobile phase was conditioned first by washing columns in sequence using methanol, aquadest, 1.0 $\mathrm{M}$ nitric acid solution in acetone, aquadest, and $1.0 \mathrm{M}$

Table 1: Protein content based on the Kjeldahl method

\begin{tabular}{lll}
\hline Pancreatin concentration (\%) & $\begin{array}{l}\text { Protein } \\
\text { conversion }\end{array}$ & $\begin{array}{l}\text { Protein } \\
\text { concentration (\%) }\end{array}$ \\
\hline 2 & 6.25 & 0.625 \\
3 & 6.25 & 0.575 \\
4 & 6.25 & 0.569 \\
\hline
\end{tabular}

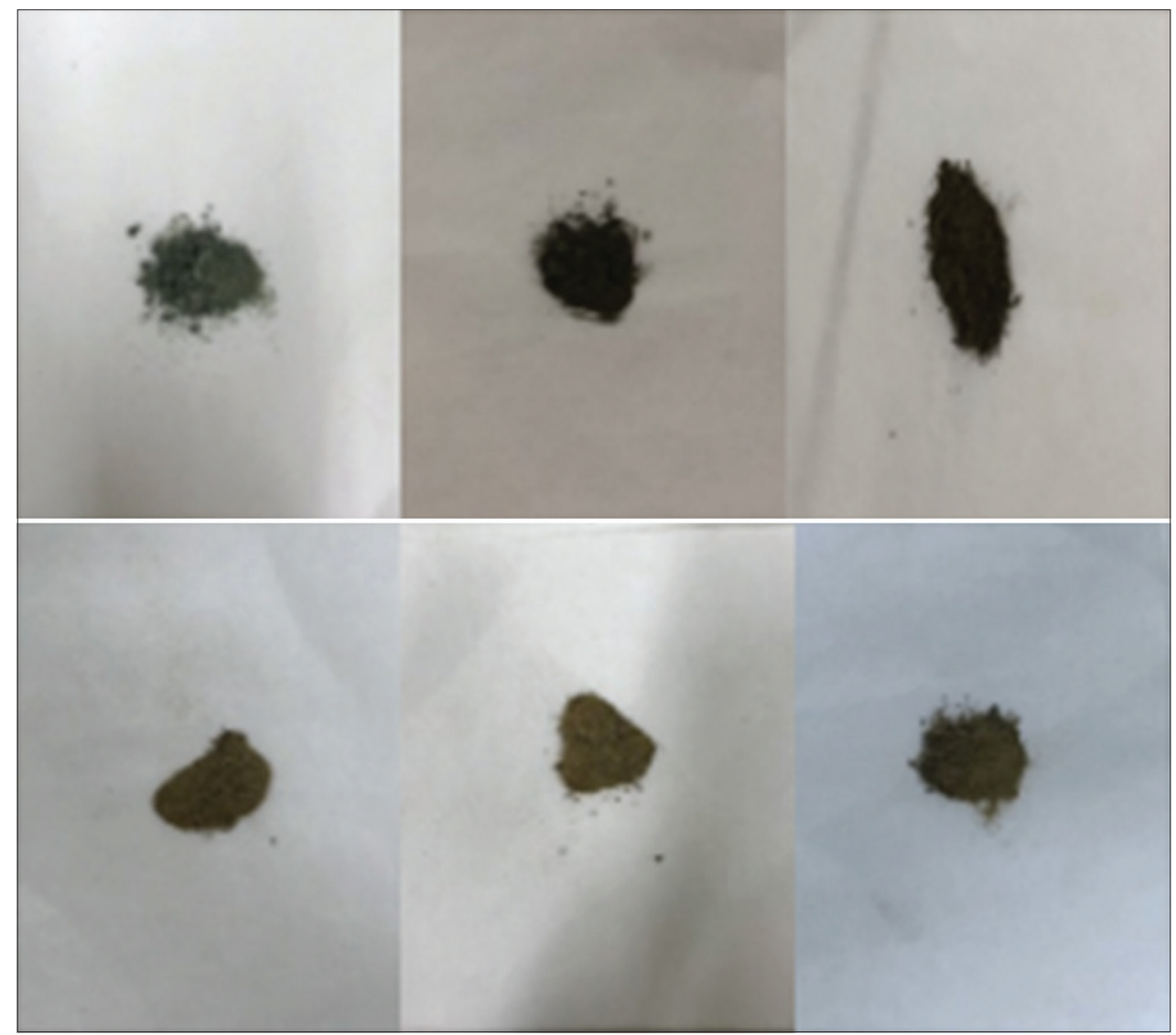

Fig. 1: (Top, from left to right) copper-proteinate complexes (0.8:1), copper-proteinate complexes (1:1), and copper-proteinate complexes (1.2:1). (Bottom, from left to right) manganese-proteinate complexes (0.8:1), manganese-proteinate complexes (1:1), and manganeseproteinate complexes $(1.2: 1)$ 
Table 2: Yield of metal proteinate complexes

\begin{tabular}{llllll}
\hline Compound name & $\begin{array}{l}\text { Protein weight } \\
\text { (mg) }\end{array}$ & $\begin{array}{l}\text { Metal weight } \\
\text { (mg) }\end{array}$ & $\begin{array}{l}\text { Complexes theoretical } \\
\text { weight (mg) }\end{array}$ & $\begin{array}{l}\text { Complexes weight } \\
\text { from synthesis (mg) }\end{array}$ & $\begin{array}{l}\text { Yield } \\
\text { (\%) }\end{array}$ \\
\hline Copper-proteinate $(0.8: 1)$ & 66.7 & 53.36 & 120.06 & 118.32 & 98.55 \\
Copper-proteinate (1:1) & 66.7 & 66.70 & 133.40 & 130.56 & 97.87 \\
Copper-proteinate (1.2:1) & 66.7 & 80.04 & 146.74 & 144.31 & 98.34 \\
$\begin{array}{l}\text { Manganese-proteinate } \\
\text { (0.8:1) }\end{array}$ & 66.7 & 53.36 & 120.06 & 117.73 & \\
Manganese-proteinate (1:1) & 66.7 & 66.70 & 133.40 & 129.47 & 97.06 \\
Manganese-proteinate & 66.7 & 80.04 & 146.74 & 144.34 & 98.36 \\
$(1.2: 1)$ & & & & \\
\hline
\end{tabular}

Table 3: Water content in metal proteinate complexes

\begin{tabular}{llll}
\hline Compound name & Weight (before heating) (g) & Weight (after heating) (g) & Water content (\%) \\
\hline Copper-proteinate $(0.8: 1)$ & 11.4706 & 11.4680 & 0.02 \\
Copper-proteinate (1:1) & 22.3542 & 22.3455 & 0.04 \\
Copper-proteinate $(1.2: 1)$ & 11.9566 & 11.9178 & 0.30 \\
Manganese-proteinate (0.8:1) & 22.3836 & 22.3743 & 0.04 \\
Manganese-proteinate (1:1) & 11.4579 & 11.4570 & 0.01 \\
Manganese-proteinate (1.2:1) & 22.3953 & 22.3908 & 0.02 \\
\hline
\end{tabular}

Table 4: Concentration of metal content in metal proteinate complexes determined by AAS

\begin{tabular}{|c|c|c|c|c|c|c|}
\hline Compound name & $\begin{array}{l}\text { Sample weight } \\
\text { (mg) }\end{array}$ & $\begin{array}{l}\text { Concentration } \\
(\mu \mathrm{g} / \mathrm{ml})\end{array}$ & $\begin{array}{l}\text { Volume } \\
\text { (ml) }\end{array}$ & $\begin{array}{l}\text { Dilute } \\
\text { factor }\end{array}$ & $\begin{array}{l}\text { Concentration } \\
\text { (mg/g) }\end{array}$ & $\begin{array}{l}\text { Bound metal concentration } \\
\text { (mg/g) }\end{array}$ \\
\hline Copper-proteinate (08:1) & 61.04 & 1.2232 & 50 & 5 & 5.0098 & 5.0098 \\
\hline Free copper $(0.8: 1)$ & 60.14 & - & 10 & 1 & - & - \\
\hline Copper-proteinate $(1: 1)$ & 60.09 & 2.4901 & 50 & 5 & 10.3599 & 10.3599 \\
\hline Free copper $(1: 1)$ & 60.23 & - & 10 & 1 & - & - \\
\hline Copper-proteinate $(1.2: 1)$ & 60.13 & 2.1623 & 50 & 5 & 8.9901 & 8.9901 \\
\hline Free copper $(1.2: 1)$ & 60.02 & - & 10 & 1 & - & - \\
\hline Free manganese $(0.8: 1)$ & 60.73 & - & 10 & 1 & - & - \\
\hline Manganese-proteinate $(1: 1)$ & 60.26 & 4.4144 & 50 & 5 & 18.3140 & 18.3140 \\
\hline Free manganese $(1: 1)$ & 60.72 & - & 10 & 1 & - & - \\
\hline Manganese-proteinate (1.2:1) & 60.40 & 4.9060 & 50 & 5 & 20.3063 & 20.2865 \\
\hline Free manganese $(1.2: 1)$ & 60.10 & 0.1191 & 10 & 1 & 0.0198 & - \\
\hline
\end{tabular}

AAS: Atomic absorption spectrophotometry

$\mathrm{NaOH}$ solution in distilled water. This process resulted in a positively charged stationary phase so that free metal ions with a positive charge do not bind to the stationary phase and elute with the mobile phase. The elution containing the metal ions was directly analyzed by an atomic absorption spectrophotometer.

\section{Determination of the metal content using AAS}

First, a calibration curve was prepared using a standard solution with a concentration of $0.1,0.5,1,2,4$, and 8 ppm for each metal. The sample levels with the conditions of each metal were determined as follows: Copper (flame: Air, acetylene [oxidation]; temperature: $2450 \mathrm{~K}$; speed: $160 \mathrm{~cm} / \mathrm{s}$; and wavelength: $324.7 \mathrm{~nm}$ ) and manganese (flame: Air, acetylene [oxidation]; temperature: $2450 \mathrm{~K}$; speed: $160 \mathrm{~cm} / \mathrm{s}$; and wavelength: $279.5 \mathrm{~nm}$ ).

\section{RESULTS AND DISCUSSION}

\section{Preparation of fish waste powder}

The powdered fish waste obtained in this study had a fishy odor and was brown in color. Loss due to drying to remove water content was $3.49 \%$.

\section{Protease enzymatic extraction of protein from fish waste}

Enzymatic hydrolysis yielded $15 \mathrm{ml}$ of protein, which was a suspension of pancreatin enzyme fish waste powder in three different ratios (2:100, 3:100, and 4:100). The protein contents obtained from these suspensions were $0.625 \%, 0.575 \%$, and $0.569 \%$ (Table 1 ). The optimum condition which yielded the highest protein content was the ratio of pancreatin enzyme to fish waste powder of 2:100. Consequently, metal proteinate complexes were synthesized using protein extracted using pancreatin from fish waste powder at a ratio of 2:100.

\section{Synthesis metal proteinate complexes}

The copper proteinate complex obtained in powder form was dark green Pantone $5743 \mathrm{U}$ color. The manganese proteinate complex was brown Pantone $464 \mathrm{U}$ color. The yield of each metal proteinate complex in various ratios is summarized in Table 2 and Fig. 1 . The water content of each metal proteinate complex in various ratios is listed in Table 3.

\section{Determination of the metal content using AAS}

The concentration of metal bound to proteins was obtained by subtracting the concentration of metal in samples that were subjected to destruction from the concentration of free metals obtained from separation. In this study, free copper was not found in copper proteinate complexes. However, free manganese was found in all manganese proteinate complexes with the highest in the 1.2:1 ratio, which amounted to $0.0198 \mathrm{mg} / \mathrm{g}$, as shown in Table 4 . The highest concentration of bound copper was in the 1:1 ratio, whereas the highest concentration of bound manganese was in the 1.2:1 ratio (Table 4).

\section{CONCLUSION}

It was found that copper and manganese can be reacted with proteins extracted from fish waste using enzymatic hydrolysis. This reaction yielded dark green Pantone $5743 \mathrm{U}$ colored copper proteinate and 
brown Pantone $464 \mathrm{U}$ color manganese proteinate in powder form. The optimum concentration of pancreatin enzyme was found to be $2 \%$ of the substrate. The yield of copper proteinate complexes ranged from $97.87 \%$ to $98.55 \%$, whereas the yield of manganese-proteinate ranged from $97.05 \%$ to $98.36 \%$. The free metal content was only found in the manganese proteinate complex in 1.2:1 ratio which was determined to be $0.0198 \mathrm{mg} / \mathrm{g}$

The copper-proteinate complex (1:1) yielded the highest amount of copper content, whereas a ratio of 1.2:1 was ideal for the highest yield of manganese proteinate complex and also the highest free metal content.

\section{CONFLICTS OF INTEREST}

The authors disclose that no conflicting interests associated with the manuscript exist.

\section{REFERENCES}

1. Food and Agriculture Organization. The State of World Fisheries and Aquaculture 2018-Meeting the Sustainable Development Goals. RomeItaly: Food and Agriculture Organization; 2018.

2. Ivanovs K, Spalvins K, Blumberga D. Approach for modelling anaerobic digestion processes of fish waste. Ener Procedia 2018;147:390-6.

3. Halim NR, Yusof HM, Sarbon NM. Functional and bioactive properties of fish protein hydolysates and peptides: A comprehensive review. Trends Food Sci Technol 2016;51:24-33.

4. Arvanitoyannis IS, Kassaveti A. Fish industry waste: Treatments, environmental impacts, current and potential uses. Int J Food Sci Technol 2008;43:726-45.

5. Morales-Medina R, Tamm F, Guadix AM, Guadix EM, Drusch S. Functional and antioxidant properties of hydrolysates of sardine ( $S$. pilchardus) and horse mackerel ( $T$. mediterraneus) for the microencapsulation of fish oil by spray-drying. Food Chem 2016;194:1208-16

6. Ghaly A, Ramakrishnan V, Brooks M, Budge S, Dave D. Fish processing wastes as a potential source of proteins, amino acids and oils: A critical review. J Microb Biochem Technol 2013;5:107-9.

7. Sila A, Bougatef A. Antioxidant peptides from marine by-products: Isolation, identification and application in food systems: A review. J Funct Foods 2016;21:10-26.

8. Zamora-Sillero J, Gharsallaoui A, Prentice C. Peptides from fish byproduct protein hydrolysates and its functional properties: An overview. Mar Biotechnol (NY) 2018;20:118-30.

9. Himonides AT, Taylor AK, Morris AJ. A study of the enzymatic hydrolysis of fish frames using model systems. Food Nutr Sci 2011;2:575-85.

10. Ashmead HH. Buffered Enzymatically Produced Metal Proteinates. US Patent; 1979.

11. Bost M, Houdart S, Oberli M, Kalonji E, Huneau JF, Margaritis I. Dietary copper and human health: Current evidence and unresolved issues. J Trace Elem Med Biol 2016;35:107-15.

12. Chen P, Bornhorst J, Aschner M. Manganese metabolism in humans. Front Biosci (Landmark Ed) 2018;23:1655-79.

13. Nielsen SS. Food Analysis Laboratory Manual. New York-USA: Springer; 2010.

14. Tokalioglu S, Kartal S, Elci L. Speciation and determination of heavy metals in lake waters by atomic absorption spectrometry after sorption on amberlite XAD-16 resin. Anal Sci 2000;16:1169-74.

15. Prabha J, Vincent S, Joseph S, Magdalene J. Bioactive and functional properties of fish protein hydrolysate from Leiognathus bindus. Asian J Pharm Clin Res 2016;9:277-81.

16. Samaranayaka AG, Kitts DD, Li-Chan EC. Antioxidative and angiotensin-I-converting enzyme inhibitory potential of a pacific hake (Merluccius productus) fish protein hydrolysate subjected to simulated gastrointestinal digestion and Caco-2 cell permeation. J Agric Food Chem 2010;58:1535-42.

17. Robinson H, Hogden C. Determination of serum protein. J Biol Chem 1941;136:853-67.

18. Rajeshkumar S, Malrakodi C, Venkat SK. Synthesis and characterization of silver nanoparticles from marine brown seaweed and its antifungal efficiency against clinical fungal pathogens. Asian J Pharm Clin Res 2017;10:190-3.

19. Mansoory JH, Rajput SS. Synthesis, reactivity and biological evaluation of triazole: Recent developments. Int J Pharm Pharm Sci 2015;7:20-32. 